\title{
Local responses to state-led municipal reform in the Finnish- Swedish border region: conflicting development discourses, culture and institutions
}

\author{
FREDRIIKA JAKOLA
}

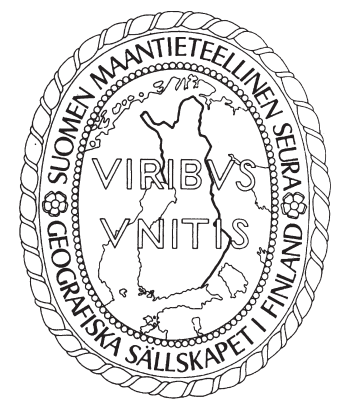

Jakola, F. (2018) Local responses to state-led municipal reform in the
Finnish-Swedish border region: conflicting development discourses,
culture and institutions. Fennia 196(2) 137-153. https://doi.org/10.11143/
fennia.69890

$\mathbf{y}$ This paper scrutinises the intersections and collisions of different development discourses in the Kemi-Tornio sub-region which lies alongside the Finnish-Swedish border within the political context of municipal reform initiated by the Finnish government in 20112015. By drawing on cultural political economy and institutional regional theory, this paper studies how local actors utilize different development discourses produced at (and producing) different scales to justify or contest the municipal amalgamation within the Kemi-Tornio region. In addition, the specific interest is on the how local institutional environment, and border location in particular, are mobilized and strategically used in these processes. The results, based on policy documents and qualitative interviews with key municipal actors, highlight the coexistence of three different, yet overlapping development discourses. While some municipal actors support the state-led development discourse with justification of economic reasoning, there is a strong opposing discourse emphasising the region's history, identity and municipal self-autonomy. The latter, interestingly, resonates with the EU's cross-border co-operation discourse; offering an alternative development strategy. Together with the pathdependent regional history, this intersection creates unbalanced power relations between municipalities both with and without a state border. Thus, this paper illustrates how different scalar discourses and institutional structures are actively utilized in municipal reform processes.

Keywords: regional development, institutions, culture, discourse, municipal reform, Finnish-Swedish border

Fredriika Jakola, Geography Research Unit P.O. Box 8000, 90014 University of Oulu, Finland. E-mail: fredriika.jakola@oulu.fi

\section{Introduction}

European border municipalities are sites where different scalar institutional structures and political discourses meet and, often, collide. However, the tensions and intersections between state and EU regional policies, and how they become intertwined with local interests in local decision making, have not been sufficiently studied. While a number of studies have been conducted in the framework of EU regional policies, often investigating the processes of re-territorialisation and re-scaling of governance practices (Knippenberg 2004; Prokkola 2008; Hansen \& Serin 2010; Nelles \& Durand 
2014), the methodological emphasis of these studies is on the transnational scale and the institutional structures of states are typically seen as rather static (such as laws and bureaucratic obstacles). This overruns both the states' active roles in the regional development of border regions and the diverse interest of local governmental actors. To fill this gap, this paper examines how these three scalar dimensions of development and the discourses they promote have come together in Northern Finland's border municipalities in the political context of the state-led municipal reform process. Although municipal reforms and amalgamations have gained a relatively large amount of academic interest during recent decades in Finland (Halme \& Kuukasjärvi 2010; Zimmerbauer \& Paasi 2013; Harjunen et al. 2017), and elsewhere in Europe (Vetter \& Kersting 2003; Harbo 2015; Terlouw 2016; Askim et al. 2017), the particular contextual environment of border regions has not been taken into account.

The Finnish government introduced a sweeping plan for municipal reform in 2011, which is considered the most radical reform ever envisioned in Finland. Two of its major objects were reform of the municipal territorial structure and reform of health care services. In this paper, the focus is on the former. The main argument behind reforming the municipal territorial structure was the economic efficiency of local governments, which, according to state government, needed to be improved to respond to endogenous demographic challenges and the more exogenous challenges resulting from changes in the global economic environment. Amalgamations were seen as a suitable way to increase the average population of municipalities, which in turn would produce economies of scale (Zimmerbauer \& Paasi 2013; Terlouw 2016). However, being one of the most decentralised OECD countries, Finland has a strong tradition of municipal self-autonomy (André \& García 2014) and with certain exceptions local governments have decision-making power over possible amalgamations. Consequently, this has created political tension between municipal and state levels.

In this paper, the implementation of municipal reform is empirically studied in the Kemi-Tornio region representing an industrialised sub-region with 6 municipalities and 63,000 inhabitants located on the Finnish side of the Finnish-Swedish border. The functional centres of this region are the two similarly sized cities of Tornio and Kemi, located only 35 kilometres apart from each other. This particular sub-region offers a fertile research context for studying the intersection of scalar development strategies for two major, yet interrelated, reasons. Firstly, the sub-region was established on the basis of economic reasoning. However, culturally and politically it is relatively divided, being based on divergent economic histories, settlement patterns and old administrative borders (Hedman 1976; Julku 1991; Teerijoki 2010). Secondly, throughout the history of Finnish independence there have been political tensions between state government and the border municipalities concerning the regional development of this area and especially operation across the state border (Jakola 2016). Moreover, the bilateral co-operation between Tornio and Haparanda (Sweden) is considered one of the model examples of successful cross-border co-operation (CBC) in the EU (e.g. Häkli 2009). Accordingly, the research questions are: 1) How do local actors utilize different development discourses produced at (and producing) different scales to justify or contest the municipal amalgamation in the Kemi-Tornio region?, and 2) How are the local institutional environment, and border location in particular, mobilized in these processes?

Theoretically, the paper is inspired by institutionalist regional approaches (Amin 1999; RodriguezPose 2013) and the cultural political economy (CPE) (see the inclusive summary by Jessop \& Sum 2013). Institutionalist approaches on local and regional development emphasise the importance of local agency and path-dependent social, cultural and political institutional conditions within regions in shaping economic development trajectories (Pike et al. 2006). Thus, institutions are seen as reasons why rather top-down development policies do not translate into desired result outcomes at the local level (Rodriguez-Pose 2013). However, the institutionalist regional approach has been criticised for having too little focus on questions of politics and scale (Tomaney 2014). Accordingly, it has argued that it is precisely "politics which mediate the relationship between institutions and economic performance" (Dellepiane-Avellaneda 2010, 211). In subscribing to this criticism, this paper uses the methodological premises of the CPE (see Jessop \& Sum 2013) to examine how local actors strategically mobilize different scales and their related development discourses and institutional structures in the political struggle for and against municipal reform. 
This relates to the question of power which is seen in this paper as the ability of to have an effect (Allen 2003) with regard to municipal amalgamation and regional development. The actors' ability to have an effect is seen, however, to be related to the surrounding institutional legacies and development discourses which can empower and/or constrain certain actors, groups, interests, strategies etc. (Cumbers \& MacKinnon 2011). Nevertheless, this relationship between ability and the surrounding institutions and discourses is not fixed but mutable and dependent on active mobilisation; power relations become materialised in local politics. Thus, while in CPE institutions are mainly understood as formal political institutions, this paper stresses the role of both formal social institutions and communal informal institutions such as norms, values and habits. Dialogue between the CPE and the institutional regional approach is needed to gain a more nuanced understanding not only about the role of the socio-cultural environment and local agency in the construction and re-scaling of economic spaces but also of the contested relations between different scales and the governmental levels participating in these processes.

The paper is structured as follows: the conceptual section scrutinises how the politicisation of regional development strategies and its scalar dimensions within certain institutional contexts can be studied by applying the ideas of the CPE. This is followed by an introduction of research material and analysis methods used. In the following chapter, the history of Finnish municipalities and municipal reforms is briefly presented to open up the particular political context and the municipalities-state positioning. The empirical analysis is presented in the next chapter and finally, the relevance of the study and the results are considered in the last chapter.

\section{Theoretical insights: the selectivity of development strategies and local institutions}

The way local and regional 'development' is defined in the context of municipal reform, and by whom, is not unproblematic but a contested and context-dependent process. The institutional legacies of any given place shape the way in which actors "define, understand, interpret and articulate what is defined and meant by local and regional development" (Pike et al. 2007, 1260) and importantly, how this 'development' should be achieved. Thus, spatial planning and policy making are in a state of constant struggle with regard to meanings and values on 'suitable' and 'right' development strategies which are played out in local everyday practices and discussions (Jensen \& Richardson 2003), not only between different governmental levels, but also between political parties and officials and politicians, for instance. These development strategies may represent different development discourses, 'commonsense understanding' on the premises of local and regional development which can be defined as "ensembles of ideas, assumption and categorisations which are produced, sustained and transformed in a particular set of practices" (Hajer 1995, 44). By giving meaning to physical and social realities, discourses produce the possibility for particular statements, practices and power relations to be valid or acceptable (Hajer 1995, 44; Cresswell 2013, 276).

In Nordic countries, the power relations between municipalities and state government are of particular interest because municipalities are traditionally seen as "extensions of the welfare state" (Dannestam 2008, 353), which are heavily dependent on state subsidies. Thus, the strong selfautonomy, which forms a crucial element of the institutional environment and identity of municipalities today, is largely explained by the crucial role of local governments in the construction of welfare states after the World Wars (Moisio 2012). Yet comprehensive state-led regional development policies were already being questioned in Northern Europe in the late 1970s and early 1980s and more local-/ regional-based development strategies and policies started to emerge, also across state borders (Prokkola 2011; Jakola 2016). However, the political discourse on the role of the state as a dominant institution of governance still prevails, and the intention of states is to strongly intervene and guide the development of the state territory as a whole. Top-down municipal reform is an immense effort by state government to use its executive power over local governments. While considering the important role of the EU'S CBC policies for local municipalities, from the perspective of state development strategies, however, EU border region policies are rarely a central concern, but appear more as a supplementary strategy and secondary to this kind of state-led development discourse (Jakola 2016). Although municipal reform and CBC schemes are not seen as contradictory on a rhetoric 
level, the question is more complex when viewed from the perspective of the daily practices of local governmental actors.

Moreover, there is broad academic and political agreement that regions and cities cannot be treated as static and univocal subjects of policy decisions and 'one-size-fits-all' development strategies, but as complex and contested political entities with diverse and multiple interests and goals with increasing potential to make their own political choices in response to these demands (Bristow 2010). Accordingly, municipal reform is not understood here through the restructuring of municipal borders or service structures per se, but it is seen primarily as a state-led development strategy which embedds the idea of state being a legitimate actor in defining and guiding the development of municipalities.

When studying municipal mergers and the guiding development discourses in the context of border municipalities, the CPE (Jessop \& Sum 2013) helps in understanding the role of meaningmaking as a method of complexity reduction and acknowledges the importance of meanings, practices and language in the study of the political economy of places (Moulaert et al. 2007, 198). According to the CPE approach, in order for a discourse to become dominant and hegemonic in society, it needs to go through evolutionary stages of variation, selection, retention and reinforcement (Jessop \& Sum 2013). Particular development discourses from a variety of discourses become 'selected' and prioritised discourses depending on their ability to interpret and explain particular events, as well as how they support particular local interests. This is followed by a process of 'retention' when discourses are built into institutional sites, roles and strategies. Finally, the process of 'reinforcement' is where these discourses are embedded in institutional structures, rules and regulations to such an extent that they become a naturalised, 'common sense' discourse (Bristow 2010, 157).

When local and regional actors make sense of the benefits of municipal mergers they need to evaluate them in the context of a changing economic and political environment. Recontextualisation and selection of particular development discourses and related policies in certain context depends on how they resonate with the institutional legacy of that region (Jessop 2001). In the Kemi-Tornio region, for some municipalities CBC has become a key development strategy as it has resonated with both the regional cultural heritage and the resources available, such as INTERREG funding. The CBC as a development strategy has become institutionalised through different common agreements and organisations. From the perspective of CPE it is crucial how a given discourse may privilege some actors and local development strategies and actions over others and how actors utilize this differential privileging through 'strategic-context analysis' (Jessop 2001, 1223; Dannestam 2008). By legitimizing certain kinds of ideas, interests, strategies, norms, regulations etc. development discourses can further the power position of some actors or organisations by increasing their abilities to have an effect on regional development.

Accordingly, politics of scale refers to "the strategies used by actors to explain, justify and defend the link between a particular scale or scalar configuration and a political project" (Gonzales 2006, 838). In the context of municipal mergers, actors mobilise and select different scales, development discourses and institutional structures to give coherence and legitimacy to their political opinions and practices concerning the territorial 'base unit' of regional development and planning, be it the municipality, the planned merged of a municipality, a cross-border region or something else. It is noteworthy, however, that actors may select a certain scale and development discourse, such as CBC, and adapt its related lexicon and rhetoric in pursuing and funding their own local interests and strategies which may not in themselves be so directly related to the wider policy objectives of the European Union, such as European economic integration or transnationalisation (Johnson 2009; Luukkonen 2011; Prokkola et al. 2015; Stoffelen \& Vanneste 2017). Thus, as Gonzales $(2006,853)$ aptly points out, "the language and rhetoric are not mere accessories"; through discursive strategies actors are normalising the space of regional development to make their political decisions seem as selfexplanatory as possible (Gonzales 2006).

\section{Research material and analysis}

The main research material consists of 21 qualitative interviews with key politicians and officials from Tornio, Kemi, Keminmaa, Tervola, Simo and Ylitornio (Fig. 1). Interviews addressed not only the 


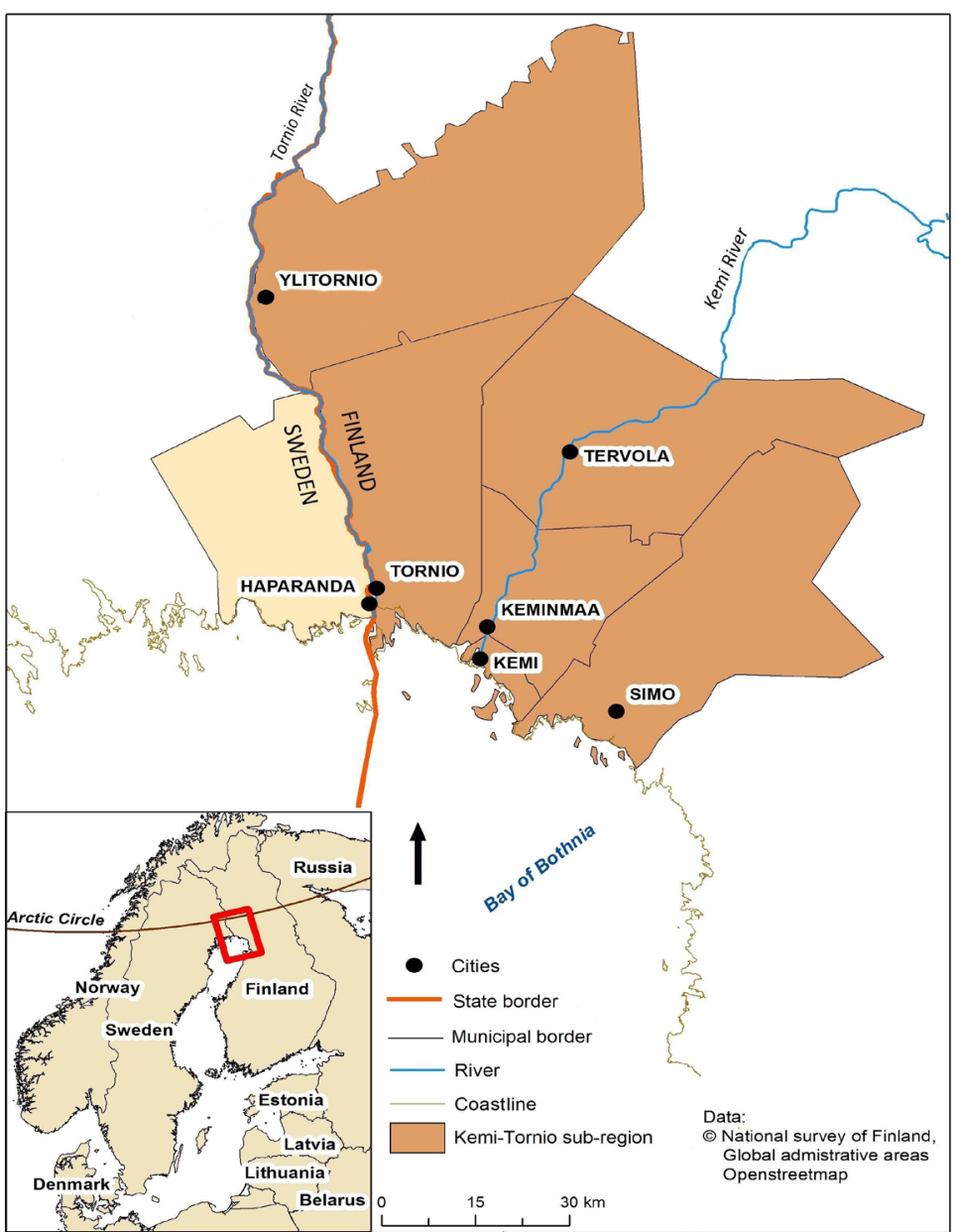

Figure 1. The study area (original layout by Mikko Kesälä, edited by the author). municipal reform process itself but also the challenges and possibilities of regional development and dynamics of municipal co-operation. The interviews were conducted in 2014 at locations suggested by the interviewees. Permission to record the interviews was granted by all (with the exception of one) and anonymity was secured by using specific codes for each interview, following responsible research conduct consistent with The Finnish Advisory Board on Research Integrity (2012). There are four interviews from each of the border municipalities of Tornio and Ylitornio, three interviews from Kemi and Keminmaa, and two from Simo. Additionally, one interview was conducted in Swedish Haparanda and one in the Development Organisation of Kemi-Tornio. In addition to interviews, key policy reports related to municipal reform from the Ministry of Finance served as contextualisation and to aid in understanding the reasoning and justification used by state government.

The research design follows

the principles of intensive research in which the objective is, through contextual studies, to understand better how causal processes, in this case the regional development path, work out in a particular area (Sayer 1992). The analysis method is based on core manners of critical discourse analysis (De Cillia et al. 1999; Hajer 2003; Fairclough 2010a), a method which helps us to identify and locate the power relations and dialogues between different actors and the development discourses they promote. Critical discourse analysis, however, is not a uniform or unproblematic method but has different variations and applications depending on whether it is based more on critical realist (Fairclough 2010a) or post-structuralist (Howarth \& Griggs 2012) traditions (Fairclough 2010b). This paper draws on the standpoints of Fairclough (and others) as it supports and enriches the political-economic theory of the CPE. In spite of their differences, concerning for instance understanding of language, they share a dialectical understanding between discourse and practice (Fairclough 2010b); how discourse constitutes social practice, such as municipal reform, while at the same time being constituted by it (De Cillia et al. 1999, 157)'.

As Sayer $(1992,248)$ aptly points out, "context is rarely just background; the exploration of how both the political and cultural institutional environment is constructed and how the key agents interact, constitute and contest it, is vital for a viable explanation". Critical discourse analysis provides particular insights into the struggle between different strategies for transforming society through rhetorically oriented analysis on how strategic differences are fought out in dialogues and debates 
between different actors (Fairclough 2010a). Local governmental practices, such as meetings, decision making or informal discussions, are sites in which power relations and conflicts between different ideas, strategies and discourses are being manifested (Hajer 2003). Here the analytical emphasis is on the practices of local politics and how interviewees discuss and construct their argumentation for or against municipal amalgamation, and which kind of alternative strategies they bring forward.

Concerning language, the focus during the analysis was on the key terms, expressive conventions and narratives; for example, narratives on regional differences, as well as on the style of language, meaning how, for instance, certain things are impressed as 'common sense'. When mapping local government practices, emphasis was put on agents - who are included and who are excluded, formal/ informal institutions, contextualisation, events, conflicts and resources that were used to legitimise particular regional development strategies (Jensen \& Richardson 2003, 59).

The analysis was conducted in two phases. In the first phase, the main reform related policy documents were thoroughly examined to ascertain the main reasons and justifications for the reform imposed by the Ministry of Finance. These were read in comparison with the literature on municipal amalgamation and the argued neoliberal ideology behind these processes. In the second phase, the ways in which local actors support or contest this strategy was examined, as was how they utilize the institutional structures and discourses produced at different scales. Although the starting point of the paper was to examine the intersection and collision of different scalar development discourses and which kind of development trajectories they result in the border regions, these three scales of local/regional, state and EU were not taken as given; however, the tensions between these three scales were strongly present in the interviews. In spite of the fact that, all of these development discourses presented in the analysis promote regional growth, the governance methods and the preferred power structures between different scalar actors and organisations vary.

\section{Municipalities under reform pressures in Finland}

With the aim of achieving economic efficiency, the territorial and functional reforms which have recently taken place in many Western European countries represent the most extensive reform activities since the Second World War (Vetter \& Kersting 2003). In Finland, municipalities have a long history and have always played a strong institutional role. The Finnish regional structure is based on the state, provinces and municipalities as "a mix of overlapping old, historical regions that have become institutionalised over time" (Zimmerbauer \& Paasi 2013, 34). Today, municipalities provide a wide range of statutory services: besides social welfare and comprehensive and upper secondary education, municipalities are responsible for land use management and infrastructure such as water and energy supply, road maintenance and waste management, but also strategic development (Kuusi 2011).

The number of municipalities has decreased slowly over the past decades in Finland; between 1940 and 2016 their number had reduced by almost half (Table 1$)^{2}$. When the building of the Finnish welfare state started after the Second World War and the municipalities' institutional role as a provider of basic public services strengthened (Jauhiainen \& Niemenmaa 2006; Moisio 2012), securing an economically efficient municipal territorial structure accordingly rose to prominence on the political agenda. In the early 1960s, the government instructed regional counties (lääni) to investigate suitable possibilities in their municipal structures, but because of political disagreements the envisioned reform never materialised (Moisio \& Uusitalo 2003).

Nevertheless, during the 1960s and 1970s voluntary municipal amalgamations were relatively frequently formed as many rural municipalities merged with urbanised municipalities (Moisio \& Uusitalo 2003). Overall co-operation between municipalities increased in the 1970s and alongside municipal mergers different kinds of federations of municipalities were created, reflecting the strengthening role of local governments and increased horizontal relations between regional- and local-level actors as well as across state borders (Prokkola 2011; Moisio 2012). In the Kemi-Tornio region as well, the history of regional co-operation between the six municipalities dates back to the 
Table 1. Fluctuation in the number of municipalities in Finland (Tilastokeskus 2017).

\begin{tabular}{c|c|c|c}
\hline Year & $\begin{array}{c}\text { Number of municipalities } \\
\text { (January 1) }\end{array}$ & Absolute change & $\begin{array}{c}\text { Mean population } \\
\text { (December 31) }\end{array}$ \\
\hline 1940 & 602 & & 6,139 \\
1960 & 548 & -54 & 8,114 \\
1980 & 464 & -84 & 10,318 \\
2000 & 452 & -12 & 11,463 \\
2010 & 342 & -110 & 15,715 \\
2016 & 313 & -29 & 17,582 \\
\hline
\end{tabular}

late 1960s when the Kemi-Tornio Regional Economic Union (after 1991, The Development Organisation of Kemi-Tornio) was established 'in order to harmonise municipalities' and the business sector's efforts to develop the regional economy' (Kemi-Tornio Talousalueliitto 1969) ${ }^{3}$. Since then, the Development Organisation of Kemi-Tornio has played an important role in lobbying the state government concerning large investments and investigating the possibilities of co-operation and a common service structure.

However, during the 1980s and 1990s there were few municipal mergers in Finland, despite the fact that the regional structure was under political discussion and other adjustments were made. When Finland joined the EU in 1995, the way development resources were allocated and structured changed significantly; they became administered at the regional level and development work became more project-based (Vartiainen 1998). The Kemi-Tornio region became an official sub-region (seutukunta) ${ }^{4}$ in 1994 when the Finnish government divided the country's municipalities into subregions in order to bring the Finnish municipal structure into compliance with the EU's NUTS4 classification. These sub-regions still did not have legitimate decision making or regulative tasks, but were based on voluntarism. EU membership effected a change in the relationship between the regions and the state in Finland. According to Moisio (2012) this was especially the case after the adoption of the so-called Lisbon Strategy in 2000, which emphasised the agential role of regional and local actors in defining their endogenous resources and development potential.

Municipal reform again appeared on the Finnish political agenda in 2006 when the PARAS project (Reform of municipal and service structures) was launched. A target minimum municipal size was set to 20,000 inhabitants, but the reform was based on voluntarism. The results were mixed, ranging from big amalgamations of several municipalities to complete inaction (Sandberg 2015). The reform process was, nevertheless, relatively successful as it resulted in over 57 amalgamations between 2006 and 2011, including 95 municipalities, and overall increased inter-municipal co-operation in Finland (Kuntaliitto 2011). However, when Prime Minister Jyrki Katainen's cabinet began their administration in 2011, they ended the PARAS project and launched a mandatory and more radical reform plan in reference to the predicted severe demographical and economic challenges of the future:

The ongoing demographic changes are challenging municipalities' ability to organise basic services in the 2020s and 2030s. The dramatic shift in the age structure and the dependency ratio over the next 20 years, domestic migration, side effects of globalisation, and the instability of both the global and Finnish economy directly threaten the operations of local governments. (Ministry of Finance 2012a, 17)

In the very first drafts of the plan, the sought-after number of municipalities was less than one hundred. A law on municipal structure came into operation in 2013, obligating municipalities to investigate potential municipal mergers. The law also re-legalised forced mergers under certain conditions. However, the government halted the process in August 2015 due to strong opposition both at the municipal and parliamentary levels. In the end, the process resulted in only a few amalgamations and the study of the Kemi-Tornio region exemplifies well how the unwillingness from the part of the municipalities is played out at the local level in a whole myriad of complex ways. 


\section{To merge or not: diverging development discourses in the Kemi-Tornio border area}

\section{State-led competitiveness discourse}

The Kemi-Tornio region, like many other small- and medium-sized sub-regions in Northern and Eastern Finland today, is dealing with development challenges arising from demographic changes and problems associated with regional economics and public budgets. Decreasing job opportunities and a diminishing and aging population (Table 2) with a high dependency ratio ${ }^{5}$ are forcing both municipalities themselves and the state government to re-evaluate municipalities' operations. In the Kemi-Tornio region there have been two studies on a municipal merger initiated by the Ministry of Finance, first in 2010 as a part of the PARAS project and again in 2014. No amalgamation resulted from these processes; in 2010 only Kemi supported the amalgamation and in the most recent reform process only Kemi and Simo were supportive. In a report from 2012 written by the working group appointed by the Ministry of Finance, the planned regional amalgamation was justified on grounds of economic functionality and on how the region needs to be developed as a whole:

The municipal amalgamation would bring together [two] city regions and their immediate municipalities, which are now developing separately. If implemented, the development challenges of this region would be efficiently met. The new municipality would largely be the functional equivalent of the region of Kemi-Tornio, which itself forms a coherent functional entity in terms of accessibility, commuting and business potential. (Ministry of Finance 2012b, 329)

It is a common argument that creating larger administrative units and merging administrative structures results in economic savings. This, however, is a controversial argument as there is no scientific agreement about the timeframe concerning when such savings would be realised (Harbo 2015; Terlouw 2016). Moreover, a recent study from Finland concludes that the PARAS project did not result in economic savings for the merged municipalities (Harjunen et al. 2017). The expected economies of scale are, however, very closely related to the broader and more universal question of competitiveness and how bigger territorial units are seen as a remedy for the challenges of globalisation and the globalised economy (Zimmerbauer \& Paasi 2013).

In the interviews, those actors supporting the amalgamation selected this state-led competitiveness discourse, in which the state was presented as a governing institution from where the initiative for structural changes needs to come. As one interviewee from Simo strongly pointed out: "Those decisions [concerning the amalgamations] should be made in Helsinki [in the central government]" -SIMO2.

It is noteworthy that the actors supporting the reform in the Kemi-Tornio region did not raise the question of money or the possibility of economic savings the amalgamation was argued to produce, probably because opposing municipalities were sceptical of how the large public loans of Kemi, particularly, would be shared between all municipalities. Conversely, they used, in addition to the possible increased legal regional legitimacy, improved 'regional competitiveness' as a primary argument, within which they referred to Kemi-Tornio's position in competition with other city regions,

Table 2. Population and job development 2000-2015 (Tilastokeskus 2017).

\begin{tabular}{l|c|c|c|c|c|c}
\hline \multirow{2}{*}{ Municipality } & \multicolumn{2}{|c|}{2000} & \multicolumn{2}{c|}{$\mathbf{2 0 1 0}$} & \multicolumn{2}{c}{2015} \\
\cline { 2 - 7 } & Population & Jobs & Population & Jobs & Population & Jobs \\
\hline Kemi & 23,689 & 10,314 & 22,537 & 9,669 & 21,758 & 8,814 \\
Keminmaa & 8,930 & 2,258 & 8,573 & 2,449 & 8,388 & 2,406 \\
Simo & 3,891 & 796 & 3,489 & 663 & 3,238 & 607 \\
Tervola & 3,895 & 1,166 & 3,444 & 1,157 & 3,195 & 932 \\
Tornio & 22,617 & 8,341 & 22,513 & 9,202 & 22,199 & 8,603 \\
Ylitornio & 5,535 & 1,699 & 4,731 & 1,411 & 4,291 & 1,310 \\
\hline Total & $\mathbf{6 8 , 5 5 7}$ & $\mathbf{2 4 , 5 7 1}$ & $\mathbf{6 5 , 2 8 7}$ & $\mathbf{2 4 , 5 5 1}$ & $\mathbf{6 3 , 0 6 9}$ & $\mathbf{2 2 , 6 7 2}$ \\
\hline
\end{tabular}


especially Rovaniemi and Oulu, both in Northern Finland. These arguments were in line with the central government's rhetoric, which emphatically emphasised the need for unity:

The biggest step toward better [development] positions would be that these municipalities would be merged. These challenges start to be so big that even Kemi and Tornio look like rather small players, even though we are middle-sized municipalities. -KEMI3

If we are talking about a city of Meri-Lappi with 65,000 inhabitants, investors will be much more interested than if there would be 30,000 inhabitants. These are just the kinds of realities we face. -SIMO2

The interviewees referred to attracting investors and people, which in itself reflects a sort of neoliberalist economic rationale of governance. They also provide evidence as to how economic processes retell certain neutrally presented 'realities', which in this case referred to increased attractiveness and the need for the municipality to reach a certain number of inhabitants, although the regional population would, in fact, remain the same. This manner of de-politicisation and normalisation of capitalist economic processes has had a vital role in the rhetoric of neoliberal development discourse (see Swyngedouw 2011). As Zimmerbauer and Paasi $(2013,34)$ aptly emphasise, "amalgamations are not merely technical, administrative acts that reduce the number of institutional regional units, but also reflect internationally dominant ideas and state policies". Presenting regions and their population as entrepreneurial 'place-sellers' in a global market fits with neoliberal ideologies which are promoted not only by the business community but also by states themselves (Bristow 2010, 8; Painter 2013).

As the institutional environment in which political decisions are made on courses of action they tend to be path-dependent, oftentimes the creation of a new path and the subsequent selection of new development strategies requires an initiation. Political and economic crises are understood to create the space for 'strategic interventions' that can significantly redirect the course of events (Jessop 2010, 346-347). Using certain indicators, such as high income tax rates and low economic selfsufficiency, Kemi and Simo have the acutest economic challenges which may force them to make radical changes, such as in this case supporting municipal amalgamation. In interviews it was noted how in 2012, when the first investigation on municipal amalgamation was underway, it was expected that Finland's sixth nuclear power plant would be placed in Simo, which would have had extensive regional economic impacts on the municipality, extending to the whole region as well. In that situation, actors in Simo did not see the municipal amalgamation suggested by the central government as preferable as it did not serve their interest at that moment.

[a key official in Simo] was bragging that we don't need co-operation; others can join Simo if they like. Now when it [the placement of nuclear power plant] didn't happen, concern is already strong... for those whose budget is weaker... -TORNIO3

This exemplifies the complexity and context-dependency of policy processes and the inherent selectivity of development strategies. Actors make plans and political decisions based on their knowledge and value evaluation on possible options at that particular moment, a process in which different interests and preferences are confolated with processes of path-dependency.

It is noteworthy as to how, in the state documents, the competitiveness and welfare rhetorics go hand in hand. As Dannestam (2008) notes, in Nordic countries the welfare state heritage has such a prominent position in society that it 'cannot' be dismissed in political life. However, it is the manifestation of the competitiveness discourse, for instance creating bigger municipal units to benefit the 'economies of scale', which is said to create and improve welfare. Accordingly, welfare and social inclusion are not understood as ideological values per se, but as things resulting from growth oriented policy actions (Dannestam 2008 citing Cochraine 2007, 86). Moreover, the welfare rhetorics are used to legitimize growth oriented policy actions.

In the case of the Kemi-Tornio region those interviewees supporting the amalgamation, however, did not come forward with the issue of improving welfare. On the contrary, welfare and social inclusion were mentioned in a few opposing arguments concerning accessibility to public services. The fear that services would move too far from the people has been widely acknowledged to be one of the main hindering issues in the municipal amalgamation processes (see Terlouw 2016). Instead of prioritizing economic saving, actors see the social aspect as being more important. 
I mean if we started counting every Euro, we would only have these high schools with 500 students [state government's recommendation]. [...] By having only high schools like that, we would have only one school in whole of Lapland. I am sure it would be cheaper to have only one high school but then people would suffer. Distances would get longer and youths could not stay home with their parents after comprehensive school. A lot of different kinds of side effects would appear. TERVOLA1

It is precisely the value of social inclusion and welfare what opposing interviewees are demanding. This kind of normalization of peoples" "right" to good accessibility to public services irrespective of where they live originates from the institutionalization of welfare state policies based on a 'social rationale' as to how the state is in the last resort responsible for the welfare of an individual, something which dates back to the end of $19^{\text {th }}$ and the beginning of the $20^{\text {th }}$ centuries (Miller \& Rose 2008). As the public services tend to be centralizing, relatively dense territorial structures and smaller units are being seen, at least to some extent, as a safety mechanism for sustaining services close to the people.

\section{The opposing discourse on local institutional legacy and regional identity}

While interviewed actors in Kemi, Simo and partly in Keminmaa supported the central government's reasoning on municipal reform, others did not see that restructuring of municipal borders would be the best and most desirable solution for improving regional growth and 'vital municipal and service structure' (Ministry of Finance 2012a) under current geographical, cultural, economic and political circumstances. These interviewees suggested alternative co-operation models such as federations of municipalities instead of an amalgamation. Accordingly, there was a strong discourse on local institutional legacy and regional identity, in which different practices, trust relations, regional narratives, values and institutional structures, such as municipal self-autonomy, are intertwined as elements of resistance and are used to legitimate the opposition to the reform (Zimmerbauer \& Paasi 2013).

Those interviewed actors opposing the state-led municipal reform constructed their argument firstly on the polarisation of the region, which according to them stems from regional history. The Kemi-Tornio region lies at the convergence of the Tornio River Valley and the Kemi River Valley. Historically, settlement patterns followed the rivers, forming distinct cultural regions. A strong narrative about the historical and cultural division between Tornio and Kemi is included in the local discourse and thus, this narrative is actively reproduced and sustained by local actors in public discussions to sustain the legitimacy of the discourse. Thereby, they may strengthen their power position and ability to have an effect with regard to decision whether municipal amalgamation is taking place or not.

There is this tribal or zonal border, each river valley forms its own tribe. The Tornio River Valley and Kemi River Valley form distinct tribes and the border between them goes somewhere around Keminmaa. They have totally different cultural heritage and spirit. -TORNIO3

They [Tornio and Kemi] are like fire and water. They are difficult to bring together. -YLITORNIO3

In addition to the cultural division, interviewed actors also emphasised the political and economic history in their argumentation. Kemi has a longer tradition of heavy industry dating back to the 1930s, while Tornio did not become an industrial city until the early 1970s. Because of a strong industrial emphasis and a large proportion of working class inhabitants, left-wing parties have traditionally had a strong dominance in the local government in Kemi, while the Centre Party have dominated in other municipal governments, mirroring the situation elsewhere in Northern Finland (Yle Kuntavaalit 2017), which can be explained by the more agriculture- and trade-oriented economic structures of these areas.

Many actors also brought forward the different decision making cultures between Tornio and Kemi which were seen as a result of the divergent political and economic histories of the cities.

Kemi is an old industrial city which has been built in a certain way. Is it a socialist ideology or whatever? But it is totally a different way to approach things. Tornio is an old agricultural city, the steel industry is a rather new business sector and that particular industrial culture hasn't developed there. The decision-making culture is totally different. -TORNIO2 
Opposing actors strategically use the discourse of regional identity, and more precisely, the narratives on 'identity of region' referring to the differing socio-cultural and symbolic characteristics and boundaries between the cities of Tornio and Kemi that have resulted through the institutionalisation process of these municipalities (Paasi 2003). However, it is not 'only' a question of using this narrative of regional differences in political struggle to promote their interests, but how it is sustained through everyday local governmental practices when they are linked with different kinds of path-dependent trust-relations, values and norms. Different decision-making cultures and failed co-operation experiences have created mistrust between actors, primarily with respect to vested interests. The actor from Kemi aptly portrays the path-dependent characteristics of trust relations and other informal institutions in the following:

It feels like this mistrust [between Tornio and Kemi] is somehow really deep... Maybe the depth has surprised me a bit [when coming from outside]. Nobody is right or wrong, just for some reason different backgrounds and paths in history have led to.... It is easier to disagree than agree [with each other] -KEMI3

This highlights the interdependency of discourse and practices and how they sustain one another. In order for discourses to remain the dominant way of understanding a surrounding society, they need to be continuously 'repaired' and reproduced by actors (Bristow 2010). This, however, is not always so intentional and strategically oriented, but sometimes the institutional legacy itself guides the development as it 'resonates' so strongly with the minds of actors and how they evaluate different development strategies in relation to this legacy, which, nevertheless, might become a burden.

The opposing discourse on local institutional legacy and regional identity questions the hegemonic power of the state and who can decide how the regional 'development' is achieved, specific to resistance identity (Castells 1997; Zimmerbaeur \& Paasi 2013). The absolute value of local autonomy as a formal institution, and the governmental power and legitimacy related to it, has itself been seen as a strong reason for opposition to municipal amalgamations (Zimmerbauer \& Paasi 2013). It seems the longer the historical and institutional basis of municipalities, the more difficult major reforms are to realise (Askim et al. 2017). The long history of sovereignty of local services and land use, not only rooted in bureaucratic institutional structures but also in peoples' identities and everyday practices, supports the sustaining of the local development discourse and gives it legitimacy. Local actors perceive that the central government does not respect municipal autonomy and top-down policies themselves, thus provoking resistance among local actors:

I myself believe that if we needed municipal mergers or if they are useful, they would emerge from the grass-roots level. Now when it is dictated from outside that you should merge with that municipality, it indeed raises more resistance. As if people here at the local level could not decide what is best for them. -TORNIO1

The central government is forcing us to go in a direction which we do not [want to]. Each municipality still has statutory self-autonomy -TERVOLA1

Related to the value of self-autonomy, one interviewee put forward the traditions of land ownership, something which has not been profoundly discussed in municipal amalgamation literature. Nevertheless, the role of land use issues in institutional change, in general, have been rather neglected (Cox 2011). In Tornio, and in other surrounding municipalities, there have been long standing traditions of owning and cultivating land which have been passed down from one generation to another starting from the general parceling of land in the mid- $18^{\text {th }}$ century. However, in Kemi this kind of tradition does not exist, firstly because of the smaller municipal area and secondly because many people have moved to this city from outside to work in the wood processing factories. This might also affect the issue that people who have grown up in communities with these kinds of land-owning traditions respond more personally to land as such and the power they feel they have over their own territory.

\section{The EU's locally contested CBC discourse}

Since the 1970s, the EU has promoted a transnational development discourse on socially cohesive and economically competitive border regions, something which is achieved through CBC funding 
schemes such as INTERREG. After Finland and Sweden joined the EU in 1995, Tornio quickly adopted the rhetoric of the EU CBC policies enabled by a strong institutional foundation of cooperation with Haparanda dating back to the 1960s and a long common cultural history in the Tornio River Valley (Jakola 2016). Therefore, Tornio has frequently utilised INTERREG A funding in their projects; the most extensive and ongoing project is called 'On the Border' in which Tornio and Haparanda are building a common city centre in order to further the development of the retail sector (Prokkola et al. 2015). Thus, CBC has become a key development strategy while co-operation with Kemi and other surrounding municipalities is seen as secondary and connected more to lobbying the central government for funds and investments than actual co-operation and development projects. Moreover, the EU's transnational discourse has furthered the institutionalisation of the CBC between Tornio and Haparanda and given it legitimacy (Jakola 2016), a factor which is used in particular when justifying the resistance to the Kemi-Tornio municipal amalgamation.

In the case of the Kemi-Tornio region, the question of competition and co-operation is crucial (Jakola \& Prokkola 2018), and this is also tightly related to municipal sovereignty. Trust-building processes across the border are easier when actors do not compete for the same economic resources and do not think their self-sovereignty is threatened. The state border as a formal institution is seen as more stable and, as the EU's CBC policies are based on voluntarism, they are seen more as enforcing the self-autonomy of local governments while municipal borders are both governed and oppressed by the central government's control of politics, thereby creating resistance among local actors. Hence, the 'strategical context analysis' done by actors in Tornio concludes that their institutional environment is more favourable for the selection of CBC as a development strategy:

It is easier to co-operate [with Haparanda] as we do not pursue the same state subsidies or education quotas, and suchlike. Although people have wondered how it can be easier to co-operate across the border.... But it is precisely like that; we can both seek means whereby we could better further our common interests. Is it from Helsinki or is it from Stockholm? This is the basic starting point. It is a totally different situation [compared to Kemi]. And the state border between us... [...] Somehow it gives security but at the same time it gives freedom; it is easier to co-operate. TORNIO2

Another aspect that influences the strategic decision to support CBC at the expense of national regional co-operation is the market value of the "Tornio-Haparanda" brand (cf. Hospers 2006). Actors in Tornio see CBC as a better development strategy for improving regional competitiveness, which in this case means attracting investors, visitors, publicity, etc., rather than co-operation or amalgamation with other regional municipalities. Mobilisation of regional history and identity has become an important means in improving regional attractiveness (Paasi 2013; Stoffelen \& Vanneste 2017). The narrative on the identity of the Torne River Valley has become an important part of marketing and development rhetoric (Jakola 2016). The Tornio River Valley has an interesting history as it formed a culturally, economically and politically united region from the $11^{\text {th }}$ century until Finland was annexed to the Russian Empire in the Treaty of Hamina in 1809 and a new border between the Kingdom of Sweden and the Russian Empire was agreed, located at the Tornio and Muonio rivers (Teerijoki 2010). This exemplifies how, in local politics, socio-cultural and economic reasoning are intertwined and can boost one another.

Some of the interviewed actors emphasised that the border location at the head of the Bay of Bothnia is an important resource for regional development, especially in terms of reaching wider markets and becoming a logistical gateway to the Arctic. Local and regional-level CBC is seen as an important tool for activating the potential development opportunities on both sides of the border. Thus, the border location is well acknowledged in the operations of the Kemi-Tornio development organisation; for most of the surrounding municipalities the border and its resources remain rather remote. Although the actors in municipalities without an actual border with Sweden would be equally eligible to apply for the same EU funds, most foresaw that only Tornio would benefit from the border and related resources from INTERREG programmes.

In an attempt to emphasise the importance of coherent regional co-operation at the Kemi-Tornio sub-region level, many actors use the discursive strategy of downplaying the significance of bilateral municipal CBC between Tornio and Haparanda. They justify their opinions by arguing that the scale of 
the bilateral CBC operation is rather small and is an insufficient response to the present economic and developmental challenges they face. Furthermore, many of the actors highlighted how the CBC should not be exclusive and some of the interviewees not only downplayed the CBC but also 're-bordered' the state border which represents the state-led discourse in which the border is divided based firstly on the constitution, but also on national socialisation.

It is really good that we have the state border there and I think people in this region have well utilised Haparanda and the border location. I think it is an important matter but it shouldn't be emphasised too much, as it somewhat hinders other forms of co-operation. When the attitude [in Tornio] is like we can't disperse our resources because we have this and that project going on in the On the Border project. -KEMI1

If Tornio sees it [Haparanda] as the only direction [for co-operation], it is wrong from the perspective of the people of Meri-Lappi [the Kemi-Tornio region]. [...] It should be remembered that the state border still hinders the co-operation. And that's a fact and it always will be. -SIMO2

Thus, the state border as a formal institution is intertwined differently in different discourses, and actors use it differently based on their own interests. This highlights the path-dependent characteristics of the border region as an operational environment. Those actors who do not operate across the border see the role of the state border differently than those who have decades of experience of CBC and have built trusted relationships based on successful projects. Over the course of time, positive personal trust relations and their materialisation may also generate institutional trust, which embeds and stabilises relationships within current co-operation networks (Murphy 2006), such as has happened in Tornio.

I have grown as a part of this twin city thing... Those politicians, many of whom are still in the municipal government, decided that we should establish a common school for Tornio and Haparanda, and I belong to the next generation that went to that school. -TORNIO1

As Jessop and Sum (2013) note, in order to be selected from the various kinds of possible alternatives, a development strategy needs to resonate on personal, organisational and institutional levels, all of which are dependent on discursive and material factors as well as on existing power relations. The surrounding municipalities do not see the border as an opportunity; mainly because of geographical distance, and the fact that Tornio stands between them, but also because, more importantly, the governance culture and the values, norms and beliefs concerning the border region as an operational environment are different.

\section{Conclusion}

This paper has scrutinised the intersections and collisions of different development discourses in the Kemi-Tornio region in the political context of municipal reform led by the Finnish government. By applying the insights of the CPE it can be observed that the way in which the selection of different scalar development discourses operates depends both on how they resonate with municipal actors' understanding about the premises and values of regional development, and on the institutional legacies of the place in question. Local governmental actors operate in a certain spatio-temporal institutional context, and in order to make the 'best possible' political decisions concerning the municipal amalgamations, they give value to certain development discourses and institutional structures (Jessop 2001).

The analysis shows that in the Kemi-Tornio region some of the actors have supported the state-led competitiveness discourse through which the municipal reform has been justified. This, however, is being challenged by a local development discourse emphasising municipal sovereignty and regional identity. Why no big amalgamation was implemented in the Kemi-Tornio region is explained by the fact that the majority of key municipal actors valued 'soft' informal factors, such as cultural differences and trust relations and self-autonomy more than 'rational' economic reasoning promoted by the central government. It is not a question of ignoring future development challenges, but a question of power and sovereignty: who can decide how regional growth is being achieved and what is 'best' for us? Although municipal reform is only one strategy pertaining to how the central government aims to control and direct the regional development of municipalities, this paper has shown that it offers a 
very interesting research framework as it brings together the questions of municipal sovereignty and local agency and their role in the restructuring of economic spaces.

Therefore, what makes the Kemi-Tornio region interesting is the border location and how the local development discourse actually resonates with the EU's CBC policies. Actors in Tornio see that the EU's regional policy actually embraces municipal autonomy and they feel more 'safe' when cooperating across the state border. Preferring cross-border co-operation to co-operation in a national setting is also related to branding and how CBC is seen to have more market value and as a better strategy to improve 'regional competitiveness'. However, actors in Tornio are not empowered only by their geographical location next to border, but also because of their and their predecessors long-term strategical focus on cross-border co-operation. This emphasises the path-dependent characteristics of border regions as operational environments. The political mobilisation of narratives of regional identity can be understood as a struggle over meaningful memories of history, and, as Stoffelen and Vanneste $(2017,8)$ point out, it "is as much future oriented as historically grounded, and thereby intrinsically power-laden" (see also Paasi 2013). In the case of the Kemi-Tornio region, these narratives are mobilised for different political purposes.

Although different forms of regional co-operation between municipalities have become a part of the everyday practices of local governmental actors in Finland, municipalities often wish to maintain their self-autonomy. The strength of municipal autonomy as a formal institution should not be underestimated. Such an institution gives legitimacy to soft informal issues such as trust relations. As socio-cultural conditions affect the political processes and decisions concerning municipal amalgamations, they cannot be considered merely as secondary factors compared to 'hard' economic rationalities. Hence, Finnish municipal reform has partly failed because the central government used its executive power to establish the schemed amalgamated municipalities and defined the 'new municipal borders' without the consent of local governments (Sandberg 2015) and irrespective of their different development trajectories. This happened, for example, in relation to CBC. Thus, it would be wise for state governments to not subordinate municipalities, but to consider them more as equal partners. This would force dialogue between both endogenic local and state-led development discourses, which is sorely needed to find far-reaching solutions for the future development challenges of local governments.

\section{Notes}

1 While in postructuralist discourse analysis practices are seen as a part of discourse (Howarth \& Griggs 2012).

2 However, this decline is partly explained by a 1944 peace treaty between Finland and the Soviet Union which moved the state border and ceded certain parts of Eastern Finland to the Soviet Union.

${ }^{3}$ Although Ylitornio is no longer either officially part of Kemi-Tornio municipal co-operation or allocating resources to the municipal co-operation, in this paper it is counted as a part of the KemiTornio sub-region.

4 Finnish sub-regions' official status was ceased in 2015.

${ }^{5}$ Dependency ratio means how many young or elderly people there are per 100 working aged persons.

\section{Acknowledgements}

I wish to express my gratitude to Anssi Paasi and Eeva-Kaisa Prokkola for their encouraging and valuable comments on earlier versions of this paper. In addition, I want to thank Katharina Koch for her helpful suggestions. The CoE RELATE has been supportive for this study, for which I am grateful. Finally, I wish to thank two anonymous referees for their thorough and constructive reviews on the previous draft.

\section{References}

Allen, J. (2003) Lost Geographies of Power. Wiley, Maiden, Oxford and Melbourne. https://doi. org/10.1002/9780470773321 
Amin, A. (1999) An institutionalist perspective on regional economic development. International Journal of Urban and Regional Research 23(2) 365-378. https://doi.org/10.1111/1468-2427.00201

André, C. \& García, C. (2014) Local Public Finances and Municipal Reform in Finland. OECD Economics Department Working No 1121, OECD Publishing, Paris.

Askim, J., Klausen, J., Vabo, S. \& Bjurstrøm, K. (2017) Territorial upscaling of local governments: a variable-oriented approach to explaining variance among Western European countries. Local Government Studies 43(4) 555-576. https://doi.org/10.1080/03003930.2017.1310102

Bristow, G. (2010) Resilient regions: re-'place'ing regional competitiveness. Cambridge Journal of Regions, Economy and Society 3(1) 153-167. https://doi.org/10.1093/cjres/rsp030

Castells, M. (1997) The Power of Identity. Blackwell, Oxford.

Cochraine, A. (2007) Understanding Urban Policy: A Critical Approach. Blackwell Publishing, Oxford.

Cox, K. (2011) Institutional geographies and local economic development. In Pike, A., RodŕiguezPose, A. \& Tomaney, J. (eds.) Handbook of Local and Regional Development, 272-282. Routledge, London.

Cresswell, T. (2013) Geographical Thought: A Critical Introduction. Wiley-Blackwell, Chichester.

Cumbers, A. \& MacKinnon, D. (2011) Putting 'the political' back into the region: power, agency and a reconstituted regional political economy. In Pike, A., Rodŕiguez-Pose, A. \& Tomaney, J. (eds.) Handbook of Local and Regional Development, 249-258. Routledge, London.

Cumbers, A., MacKinnon, D. \& McMaster, R. (2003) Institutions, power and space: assessing the limits to institutionalism in economic geography. European Urban and Regional Studies 10(4) 325342. https://doi.org/10.1177/09697764030104003

Dannestam, T. (2008) Rethinking local politics: towards a cultural political economy of entrepreneurial cities. Space and Polity 12(3) 353-372. https://doi.org/10.1080/13562570802515267

De Cillia, R., Reisigl, M., \& Wodak, R. (1999) The discursive construction of national identities. Discourse \& Society 10(2) 149-173. https://doi.org/10.1177/0957926599010002002

Dellepiane-Avellaneda, S. (2010) Review article: Good governance, institutions and economic development: beyond the conventional wisdom. British Journal of Political Science 40(1) 195-224. https://doi.org/10.1017/S0007123409990287

Fairclough, N. (2010a) Critical Discourse Analysis: The Critical Study of Language. 2nd ed. Pearson, Harlow.

Fairclough, N. (2010b) Critical discourse analysis and critical policy studies. Critical Policy Studies 7(2) 177-197. https://doi.org/10.1080/19460171.2013.798239

Gonzales, S. (2006) Scalar narratives in Bilbao: a cultural politics of scales approach to the study of urbam policy. International Journal of Urban and Regional Research 30(4) 836-857. https://doi. org/10.1111/j.1468-2427.2006.00693.x

Hajer, M. (1995) The Politics of Environmental Discourse: Ecological Modernization and the Policy Process. Clarendon Press, Oxford.

Hajer, M. (2003) A frame in the fields: policymaking and the reinvention of politics. In Hajer, M. \& Wagenaar, H. (eds.) Deliberative Policy Analysis: Understanding Governance in the Network Society, 88-110. Cambridge University Press, Cambridge. https://doi.org/10.1017/CBO9780511490934.005

Halme, E. \& L. Kuukasjärvi (2010) Uusi kunta vai kuntaliitos: kuntalaisen itsehallinto. Kunnallisalan kehittämisäätiön Polemia-sarjan julkaisu nro 76. Vammalan Kirjapaino Oy, Sastamala.

Hansen, P. \& Serin, G. (2010) Rescaling or institutional flexibility? The experience of the cross-border Øresund region. Regional and Federal Studies 20(2) 201-227. https://doi. org/10.1080/13597561003731646

Harbo, L. (2015) A new wave of reforms sweeping over the Nordic countries. Nordregio News 3 1-5.

Harjunen, O., Saarimaa, T. \& Tukiainen, J. (2017) Political Representation and Effects of Municipal Mergers. VATT Working Papers 98. VATT Institute for Economic Research, Helsinki.

Hedman, O. (1976) Kemin historia 2. Pohjolan Sanomat Oy offsetpaino, Kemi.

Howarth, D. \& Griggs, S. (2012) Poststructuralist policy analysis: discourse, hegemony and critical explanation. In Fischer, F. \& Gottweis, H. (eds.) The Argumentative Turn Revisited: Public Policy as Communicative Practice, 305-342. Duke University Press, Durham and London.

Hospers, G. (2006) Borders, bridges and branding: the transformation of the Oresund region into an imaged space. European Planning Studies 14(8) 1015-1033. https://doi. org/10.1080/09654310600852340

Häkli, J. (2009) Boundaries of trust: building a transnational space in Haparanda-Tornio. In Häkli, J. \& Minca, C. (eds.) Social Capital and Urban Networks of Trust, 205-232. Ashgate, Aldershot. 
Jakola, F. (2016) Borders, planning and policy transfer: historical transformation of development discourses in the Finnish Torne Valley. European Planning Studies 24(10) 1806-1824. https://doi.or g/10.1080/09654313.2016.1194808

Jakola, F. \& Prokkola, E-K. (2018) Trust building or vested interest? Social capital processes of crossborder co-operation in the border towns of Tornio and Haparanda. Tijdschrift voor Economische en Sociale Geografie 109(2) 224-238. https://doi.org/10.1111/tesg.12279

Jauhiainen J. S. \& Niemenmaa, V. (2006) Alueellinen suunnittelu. Vastapaino, Tampere.

Jensen, O. B., \& Richardson, T. (2003) Making European Space: Mobility, Power and Territorial Identity. Routledge, London. https://doi.org/10.4324/9780203401972

Jessop, B. (2001) Institutional re(turns) and the strategic-relational approach. Environment and Planning A 33(7) 1213-1235. https://doi.org/10.1068/a32183

Jessop, B. (2010) Cultural political economy and critical policy studies. Critical Policy Studies 3(3-4) 336-356. https://doi.org/10.1080/19460171003619741

Jessop, B. \& Sum, N. L. (2013) Towards a Cultural Political Economy: Putting Culture in Its Place in Political Economy. Edwar Elgar Publishing Limited, Cheltenham.

Johnson, C. (2009) Cross-border regions and territorial restructuring in Central Europe: room for more transboundary space. European Urban and Regional Studies 16(2) 177-191. https://doi. org/10.1177/0969776409102190

Julku, K. (1991) Kemin ja Tornion vanha raja. Studia Historica Septentrionalia 19.

Kemi-Tornio Talousalueliitto (1969) Toimintakertomus 1969. Kemi-Tornion Talousalueliitto, Kemi.

Knippenberg, H. (2004) The Maas-Rhine Euroregion: a laboratory for European integration? Geopolitics 9(3) 608-626. https://doi.org/10.1080/14650040490478675

Kuntaliitto (2011) Paras-hanke tuotti 59 kuntaliitosta: rakenneuudistukset eivät tuota pikavoittoja. <https://www.sttinfo.fi/tiedote/paras-hanke-tuotti-59-kuntaliitosta-rakenneuudistukset-eivat-tuotapikavoittoja?publisherld $=2133 \&$ releaseld $=52666>$. 5.10.2018.

Kuusi, S. (2011) The Local Government System in Finland. Kuntaliitto, Helsinki.

Luukkonen, J. (2011) Europeanization of spatial planning: exploring the spatialities of European integration. PhD dissertation. Department of Geography, University of Oulu, Oulu.

Miller, P. \& Rose, N. (2008) Governing the Present. Polity Press, Cambridge.

Ministry of Finance (2012a) Elinvoimainen kunta- ja palvelurakenne. Kunnallishallinnon rakennetyöryhmän selvitys. OSA 1 Selvitysosa. Valtionvarainministeriö, Helsinki.

Ministry of Finance (2012b) Elinvoimainen kunta- ja palvelurakenne. Kunnallishallinnon rakennetyöryhmän selvitys. OSA 2 Alueellinen tarkastelu. Valtionvarainministeriö, Helsinki.

Moisio, S. (2012) Valtio, alue, politiikka: Suomen tilasuhteiden sääntely toisesta maailmansodasta nykypäivään. Vastapaino, Tampere.

Moisio, A.\&Uusitalo, R.(2003) Kuntienyhdistymistenvaikutuksetkuntien menoihin. Sisäasiainministeriön monistamo, Helsinki.

Moulaert, F., Martinelli, F., Gonzáles, S. \& Swyngedouw, E. (2007) Introduction: social innovation and governance in European cities. European Urban and Regional Studies 14(3) 195-209. https://doi. org/10.1177/0969776407077737

Murphy, J. (2006) Building trust in economic space. Progress in Human Geography 30(4) 427-450. https://doi.org/10.1191/0309132506ph617oa

Nelles, J. \& Durand, F. (2014) Political rescaling and metropolitan governance in cross-border regions: comparing the cross-border metropolitan areas of Lille and Luxembourg. European Urban and Regional Studies 21(1) 104-122. https://doi.org/10.1177/0969776411431103

Paasi, A. (2003) Region and place: regional identity in question. Progress in Human Geography 27(4) 475-485. https://doi.org/10.1191/0309132503ph439pr

Paasi, A. (2013) Regional planning and the mobilization of 'regional identity'. From bounded spaces to relational complexity. Regional Studies 47(8) 1206-1219. https://doi.org/10.1080/00343404.201 2.661410

Painter, J. (2013) Regional biopolitics. Regional Studies 47(8) 1235-1248. https://doi.org/10.1080/0034 3404.2011.653333

Pike, A., Rodriguez-Pose, A. \& Tomaney, J. (2006) Local and Regional Development. Routledge, Abingdon, Oxon. https://doi.org/10.4324/9780203003060

Pike, A., Rodriguez-Pose, A. \& Tomaney, J. (2007) What kind of local and regional development and for whom. Regional Studies 41(9) 1253-1269. https://doi.org/10.1080/00343400701543355

Prokkola, E. K. (2008) Making bridges, removing barriers. Cross-border cooperation, regionalization and identity at the Finnish-Swedish border. PhD dissertation. Department of Geography, University of Oulu, Oulu. 
Prokkola, E. K. (2011) Cross-border regionalization, the INTERREG III A initiative, and local cooperation at the Finnish-Swedish border. Environment and Planning A 43(5) 1190-1208. https://doi. org/10.1068/a43433

Prokkola, E. K., Zimmerbauer, K., \& Jakola, F. (2015) Performance of regional identity in the implementation of European cross-border initiatives. European Urban and Regional Studies 22(1) 104-117. https://doi.org/10.1177/0969776412465629

Rodriguez-Pose, A. (2013) Do institutions matter for regional development? Regional Studies 47(7) 1034-1047. https://doi.org/10.1080/00343404.2012.748978

Sandberg, S. (2015) Why did the Finnish local government reform of 2011 fail? Nordregio News 3 11-

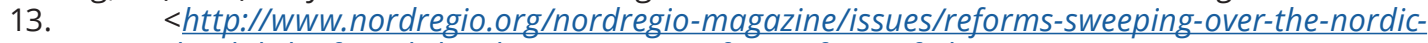
countries/why-did-the-finnish-local-government-reform-of-2011-fail/s.

Sayer, A. (1992) Method in Social Science. Revised $2^{\text {nd }}$ ed. Routledge, London and New York.

Stoffelen, A. \& Vanneste, D. (2017) The role of history and identity discourses in cross-border tourism destination development: a Vogtland case study. Journal of Destination Marketing \& Management 8 204-213. https://doi.org/10.1016/j.jdmm.2017.04.003

Swyngedouw, E. (2011) Interrogating post-democratization: reclaiming egalitarian political spaces. Political Geography 30(7) 370-380. https://doi.org/10.1016/j.polgeo.2011.08.001

Teerijoki, I. (2010) Tornion historia 3, 1918-2000. WS Bookwell Oy, Porvoo.

The Finnish Advisory Board on Research Integrity (2012) Guidelines of the Finnish Advisory Board on Research Integrity 2012. Finnish Advisory Board on Research Integrity, Helsinki.

Terlouw, K. (2016) Territorial changes and changing identities: how spatial identitities are used in the up-scaling of local government in the Netherlands. Local Government Studies 42(6) 938-957. https://doi.org/10.1080/03003930.2016.1186652

Tilastokeskus (2017) StatFin-tilastotietokanta. <http://tilastokeskus.fi/tup/statfin/index.html>. 5.10.2018.

Tomaney, J. (2014) Region and place I: institutions. Progress in Human Geography 38(1) 131-140. https://doi.org/10.1177/0309132513493385

Vartiainen, P.(1998)Suomalaisenaluepolitiikankehitysvaiheita.Sisäasiainministeriö, Aluekehitysosasto.

Vetter, A. \& Kersting, N. (2003) Democracy versus efficiency? Comparing local government reforms across Europe. In Kersting, N. \& Vetter, A. (eds.) Reforming Local Government in Europe: Closing the Gap between Democracy and Efficiency, 11-28. Springer, Opladen.

Zimmerbauer, K. \& Paasi, A. (2013) When old and new regionalism collide: deinstitutionalization of regions and resistance identity in municipality amalgamations. Journal of Rural Studies 30 31-40. https://doi.org/10.1016/j.jrurstud.2012.11.004

Yle Kuntavaalit (2017) Maakunnat. <https://vaalit.yle.fi/tulospalvelu/kv2017/maakunnat>. 5.10.2018. 